\title{
Humanized (SCID) Mice as a Model to Study human Leukemia
}

\author{
Ji Yoon Lee ${ }^{1,2}$, Donghyun Curt Kim ${ }^{3}$ and Hee-Je Kim ${ }^{1, \dagger}$ \\ ${ }^{1}$ Cancer Research Institute, Department of Hematology, Catholic Blood and Marrow Transplantation Center, \\ College of Medicine, The Catholic University of Korea, Seoul 137-701, Korea \\ ${ }^{2}$ Severance Biomedical Science Institute, Yonsei University College of Medicine, Seoul 120-752, Korea \\ ${ }^{3}$ Northeastern University School of Pharmacy, Boston, MA, USA
}

\begin{abstract}
A humanized mice (hu-mice) model is extremely valuable to verify human cell activity in vivo condition and is regarded as an important tool in examining multimodal therapies and drug screening in tumor biology. Moreover, hu-mice models that simply received human CD $34^{+}$blood cells and tissue transplants are also overwhelmingly useful in immunology and stem cell biology. Because generated hu-mice harboring a human immune system have displayed phenotype of human $\mathrm{CD} 45^{+}$hematopoietic cells and when played partly with functional immune network, it could be used to evaluate human cell properties in vivo. Although the hu-mice model does not completely recapitulate human condition, it is a key methodological factor in studying human hematological malignancies with impaired immune cells. Also, an advanced humanized leukemic mice (hu-leukemic-mice) model has been developed by improving immunodeficient mice. In this review, we briefly described the history of development on immunodeficient SCID strain mice for hu-and hu-leukemic-mice model for immunologic and tumor microenviromental study while inferring the potential benefits of hu-leukemic-mice in cancer biology.
\end{abstract}

Key Words: Humanized, Mice model, Acute myeloid leukemia

\section{INTRODUCTION}

The humanized mice (hu-mice) model is commonly reconstituted with human blood-derived $\mathrm{CD} 34^{+}$stem cells using immune compromised mice such as SCID (Bosma et al., 1983) and Rag ${ }^{\text {null }}$ strain mice (Mombaerts et al., 1992). An advanced hu-mice model has already been developed by increasing the defected function of immune cells and hu-mice with impaired natural killer cells is an emerging innovative model to study human diseases. The hu-mice

\footnotetext{
*Received: June 22, 2015 / Accepted: June 29, 2015

${ }^{\dagger}$ Corresponding author: Hee-Je Kim. Division of Hematology, Department of Internal Medicine Catholic Blood and Marrow Transplantation Center Seoul St. Mary's Hospital, College of Medicine The Catholic University of Korea 222 Banpodaero, Seochogu Seoul 137-701, Korea.

Tel: +82-2-2258-6054, Fax: +82-2-599-3589

e-mail: cumckim@catholic.ac.kr

(O)The Korean Society for Biomedical Laboratory Sciences. All rights reserved.
}

model is mainly divided into four classes including NOD/ LtSz-scid IL2R $\gamma^{\text {null }}$ (termed NSG, generated from Jackson Lab), NODShi.Cg-PrkdcscidIL2R $\gamma^{\text {trunc }}$ (termed NOG, generated from Central Institute for Experimental Animals), $\mathrm{BALB} / \mathrm{c}-\mathrm{Rag} 2^{\text {null }} \mathrm{IL} 2 \mathrm{R} \gamma^{\text {null }}$ (termed BRG, generated from Yale Univ.) and Stock-H2 ${ }^{\mathrm{d}}-\mathrm{Rag} 2^{\text {null }} \mathrm{IL} 2 \mathrm{R} \gamma^{\text {null }}$ (termed $\mathrm{H} 2^{\mathrm{d}} \mathrm{RG}$, generated from Pasteur Institute) (Shultz et al., 2007). Because these mice display a long life span, impaired innate/ adaptive immunity, and engage in the development of hematopoietic lineage cells of donors, these immunodeficient mice are regarded as having a strong strain to sustain human cell engraftment. Since NOD/SCID mutated mice from the CB17-scid mice can allow superior engraftment of human cells (Shultz et al., 1995) than nude and SCID mice, the hu-mice model using NOD/SCID and Rag2 $2^{\text {null }} \operatorname{IL} 2 \mathrm{R} \gamma^{\text {null }}$ strain mice has been used recently due to loss of murine immune network in immunology fields (Goldman et al., 
1998; Kollet et al., 2000; Ishikawa et al., 2005). This progression in the hu-mice model can be used as an effective tool in understanding normal human hematopoiesis including immune cells in vivo (Lubin et al., 1991; Lapidot et al., 1992; Huntington et al., 2009). Amid many biomedical researches, the hu-mice model can extremely facilitate the study of hematopoietic malignancies such as acute myeloid leukemia (AML). Because AML is heterogeneous and because complex issue with impaired immune system and disease prognosis is thoroughly variable, data from in vitro or ex vivo in AML have limitations in mimicking and understanding the natural propagation of AML, so the establishment of effective humanized leukemic mice (hu-leukemicmice) model is a priority in AML study (Sawyers et al., 1992; Lee et al., 2014). Indeed, results from a culture dish cannot fully represent leukemogenic events in a microenvironment. Thus, immune compromised hu-leukemicmice model is regarded as more precise tool to investigate relevance between the immune cells and HSCs/LSCs in presenting patient's environment. Since Mercier FE et al. highlighted the importance of communication between immune cells and hematopoietic cells in bone marrow (BM) indicating microenvironmental orchestration (Mercier et al., 2012), immune crosstalk with hematopoiesis and leukemogenesis is an emerging issue in microenvironmental biology. Microenvironmental domains in leukemia possess cellular components including osteoblasts, reticular cells, endothelial cells, mesenchymal stromal/stem cells, immune cells as well as non-cellular cytokines (Kfoury and Scadden, 2015; Kim et al., 2015). Especially, chemotherapy-resistant leukemic cells are typically able to change niche compositions, including in immune and stromal cells. Their mutual interaction can cause leukemia to adversely develop without blast apoptosis (Konopleva et al., 2002) or directly suppress the relapse of leukemia by enhancing of immune cells cytotoxic machinery (Zheng et al., 2012). Hu-leukemic-mice model is absolutely necessary to figure out the AML vivo phenomenon with acquiring confident evidence. Here, we briefly summarized hu-or hu-leukemic-mice models in SCID strain with injection of human cells and suggest the necessity of hu-mice models in biomedical research, especially for leukemia.

\section{Development of hu-mice model}

Since the generation of the CB17-Prkdc ${ }^{\text {scid }}$ severe combined immunodeficiency (SCID) mice model by Bosma GC et al., improvements of hu-mice model have been successively developed (Bosma et al., 1983). In 1988, Namikawa $\mathrm{R}$ and Mosier $\mathrm{DE}$ et al. first reported the injection of human immunodeficiency virus-1 and human peripheral blood leukocytes into SCID-hu mice, respectively (Mosier et al., 1988; Namikawa et al., 1988). Generation of SCID has been established in Balb/c, B6, B17, and AKR backgrounds and SCID model can provide high efficacy in grafting human cells, compared to that of nude mice. In 1988, both Weissman IL and Wilson DB groups published that human fetal liver derived hematopoietic cells and peripheral blood leukocyte (PBL) cells injected into SCID mice, respectively (McCune et al., 1988; Mosier et al., 1988). However, Weissman IL group failed to show functional immune network and only presented human phenotype in PB status. Leukocytes contain rare population for stem cells, which can produce all hematopoietic cells lineages, and show severe variation in reproducing human cell engraftments (Mosier et al., 1988). Meanwhile, human stem cells enriched $\mathrm{BM}$ was first used into irradiated $\mathrm{Balb} / \mathrm{C}$ mice by Lubin I et al (Lubin et al., 1991). Because irradiation partly plays a role in frustrating murine hematopoietic cells, the irradiated condition is similar to SCID mice. However, immune reconstitution after transplantation in irradiated $\mathrm{Balb} / \mathrm{C}$ was delayed and displayed low efficacy for immune phenotype. At 1992, Lapidot T et al. used SCID strain and reported that a stable hu-mice model using BM cells with IL-3 and GM-CSF was established and that it can allow immature human hematopoietic cells, implying that the disease model is available (Lapidot et al., 1992). Nevertheless, a disadvantage of the SCID strain found that it is the low frequency of functional immune cells. Also, engraftment efficiency is higher in human tumors or viruses rather than in human primary cells. To overcome these issues, the development of immunodeficient non-obese diabetic (NOD) /SCID mice as a second breakthrough was advanced (Shultz et al., 1995). Natural killer (NK)-cell activity, which is a main 
obstacle in the engraftment of human HSCs (Christianson et al., 1996), was lower and HSC engraftments were higher in NOD/SCID than in SCID mice (Shultz et al., 1995).
Despite constantly being advanced in the NOD/SCID model, drawbacks still remain to be resolved such as the low efficiency of engraftments of human cells, short life span,

\section{The Road to Humanized (SCID) Mice for Immunology}

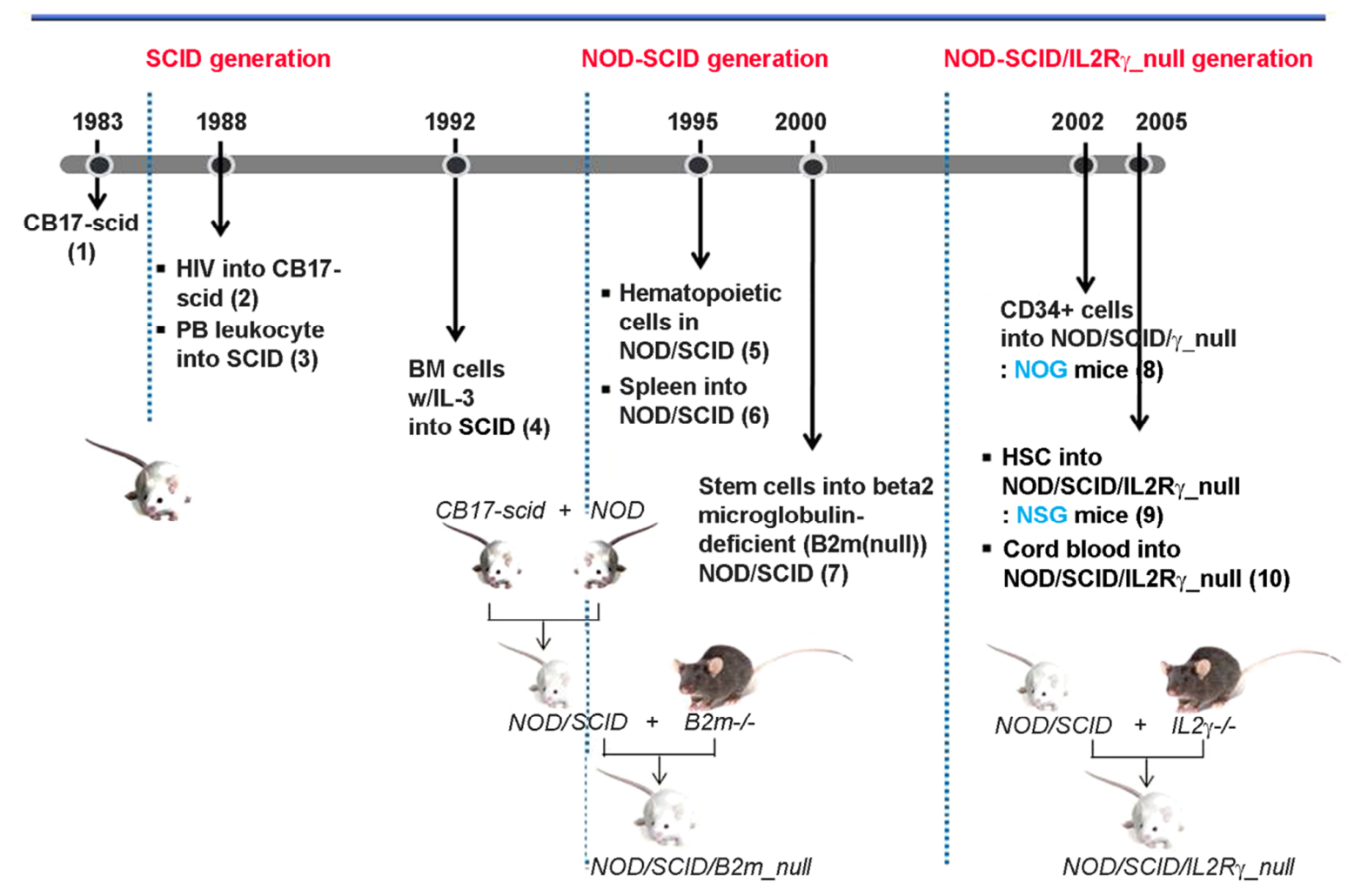

\begin{tabular}{|l|l|l|l|l}
\hline & Year & PMID & Journal, Author & Cell sources \& used mouse strain \\
\hline \hline$(1)$ & 1983 & 6823332 & Nature, Bosma GC et al & CB17SCID mice generation \\
\hline$(2)$ & 1988 & 3201256 & Science, Namikawa R et al & HIV to SCID \\
\hline$(3)$ & 1988 & 2970594 & Nature, Mosier DE et al & Peripheral blood Leukocyte into SCID \\
\hline$(4)$ & 1992 & 1372131 & Science, Lapidot T et al & BM with IL-3 to SCID \\
\hline$(5)$ & 1995 & 7995938 & J Immunol, Shultz LD et al & Hematopoietic cells into NOD/SCID \\
\hline$(6)$ & 1995 & 7717456 & Am J Pathol, Greiner DL et al & Spleen to NOD/SCID \\
\hline$(7)$ & 2000 & 10807775 & Blood, Kollet O et al & Cord blood mononucelar cells to NOD/SCID/B2m_null \\
\hline$(8)$ & 2002 & 12384415 & Blood, Ito M et al & CD34+ Stem cells to NOD/SCID/ $\gamma(\mathrm{c})$ null (NOG mice) \\
\hline$(9)$ & 2005 & 15879151 & J Immunol, Shultz LD et al & Hematopoietic stem cells to NOD/SCID/IL2R $\gamma \_n u l l$ (NSG mice) \\
\hline$(10)$ & 2005 & 15920010 & Blood, Ishikawa F et al & Cord blood cells to NOD/SCID/IL2R $\gamma \_n u l l$ \\
\hline
\end{tabular}

Fig. 1. History of hu-mice model. SCID generation and NOD/SCID generation leads to advanced NOD/SCID/IL2R $\gamma \_$null mouse, which induce depletion of innate natural killer cells as well as B, T lymphocytes. 
the frequent occurrence of thymic lymphoma, and residual NK cell activity. Thus, the third breakthrough mice model was focused on interlukin-2 receptor (IL-2R) $\gamma$ chain (Ito et al., 2002; Ishikawa et al., 2005; Shultz et al., 2005). Ishikawa $F$ et al. first showed newborn NOD/SCID/IL2R $\gamma^{\text {null }}$ mice using $\mathrm{CD} 34^{+} \mathrm{HSC}$ results in complete hematopoietic system containing platelets and red blood cells (Ishikawa et al., 2005). IL-2 receptor is a pivotal receptor for IL-2, IL-4, and IL-7 ligands to improve immunologic activation and in the development of NK cells and T, B lymphoid lineage cells (Cao et al., 1995; DiSanto et al., 1995; Ohbo et al., 1996). By depletion of the IL $2 \mathrm{R} \gamma$ chain, improved phenotype was observed such as the loss of thymic lymphoma and absolutely down regulated NK activity. The completion of this model in the development of hu-mice models is remarkable proficiency. In addition, modification of stem cell sources including CD $34^{+} \mathrm{BM}, \mathrm{PB}$ cells, cord blood derived cells, and spleen cells was also attempted to produce more effective hu-mice models (Humeau et al., 1999; Lee et al., 2014). History of hu-mice model is briefly presented by Fig. 1 .

\section{Development of hu-leukemic mice model}

AML is one of the hematologic malignancies, which occurs by immature blast accumulation with dysfunctional immune network (Lion et al., 2012; Lee et al., 2014). Additionally, uncontrolled blast proliferation results in abnormal hematopoietic cells in BM and PB (Ferrara and Schiffer, 2013). The properties of leukemia cells and the dynamic interaction of leukemia cells in a microenvironment, otherwise denoted as a "niche", is closely comprehended by the hu-mice model, but not through vitro experiments. Although an AML patient's derived cells can be isolated and studied in vitro, there are many unsolved questions that remain to be addressed due to unexpected individual variations. To overcome this weakness, the hu-mice model was first applied to study AML. AML cells and human leukemic promyelocytes of the HL-60 lines were subcutaneously injected into nude mice (Palu et al., 1979; Potter et al., 1984), which suppressed the number of $\mathrm{T}$ cells due to an absent thymus (Pantelouris, 1968). Despite the useful benefits of nude mice, it is not enough to develop a proper huleukemic-mice model due to vitalization of innate immune cells. Thus, AML patient derived primary cells were applied to SCID strain mice by De Lord C (De Lord et al., 1991) several years later after SCID mice were generated by Bosma GC et al. (Bosma et al., 1983). Because the cells were intravenously implanted into irradiated SCID mice, a model is a more preferential situation with leukemic condition. However, this study only showed that human AML cells are higher in engraftment than in HL-60 cell lines, but both primary AML cells and cell lines still sustain low frequency of human cells in PB less than 9\%. Unlike in AML, acute lymphoid leukemia (ALL) patients derived from primary cells displayed high rates of engraftment, suggesting variation of model stabilization based on cell sources (De Lord et al., 1991). Many attempts have been made to develop hu-leukemic-mice models with stable engraftment of human cells. For instance, a leukemia induced hu-mice model can be accessible to direct investigation in human tissues such as through secondary/tertiary transplantation of leukemic stem cells (LSCs) and niche study. Ever since embryonic rest theory was formulated in 1867 by Julius Cohnheim, stating that cancers are derived from rest embryonal cells in adult tissues, various approaches have been carried out to identify LSCs using hu-leukemic mice model. BM is one of the representative tissues containing LSCs, which also leads to the relapse of leukemia. To understand LSCs, studies of a leukemic microenvironment should be entailed with LSCs interaction. Recapitulated environments such as human bone fragments and BM cells were applied into SCID mice and revealed that biologic features of the leukemia guaranteed better than previously. Similar to normal hematopoietic stem cells, the frequency of leukemic stem or initiating cells is rare and most AML cells can rapidly lose their proliferative potential, when blasts free from niche. To identify LSCs, Lapidot $\mathrm{T}$ et al. first addressed the $\mathrm{CD} 34^{+} \mathrm{CD} 38^{-}$population as putative leukemic initiating cells using the SCID mice model (Lapidot et al., 1994). This result strongly provides the possibility that hu-leukemic mice are only available as a model to identify bona fide LSCs. As expected, SCID mice could express mature lymphocyte meaning leakiness, which is one of the 
reasons for SCID defect. Because residual lymphocytes cannot allow engraftment of leukemic stem cells, some investigators performed irradiation to remove murine immune cells (Shpitz et al., 1994). These efforts partly led to in- crease short-term engraftment of human cells, unfortunately, recipient murine die early on in the experimental schedule. Thus, Bonnet D et al., who is another colleague of Dick JE, used NOD/SCID mice to build a hu-leukemic-mice model.

\section{The Road to Humanized (SCID) Mice for Acute Myeloid Leukemia}

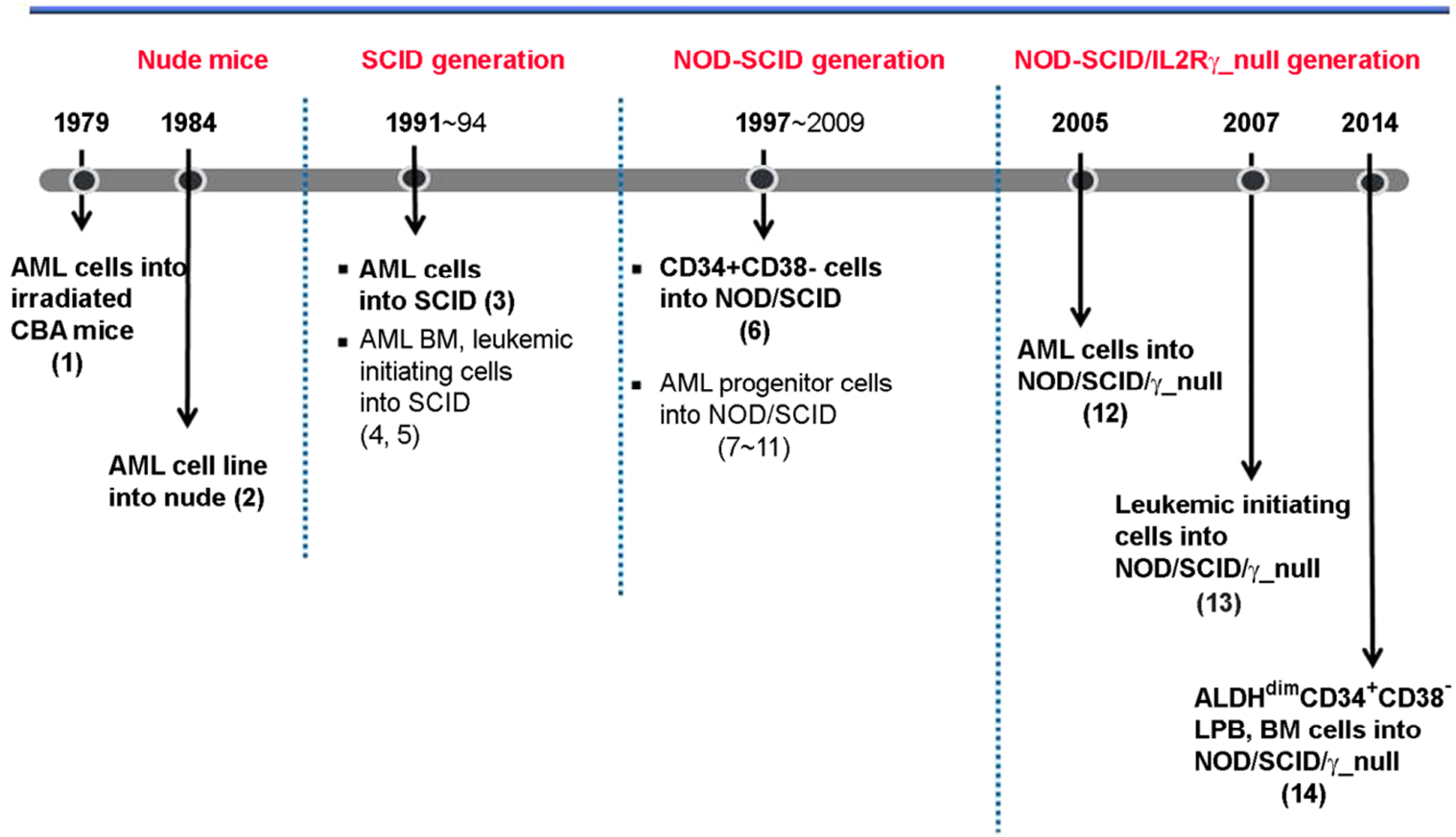

\begin{tabular}{|c|c|c|c|c|}
\hline & Year & PMID & Journal, Author & Cell sources $\&$ used mouse strain \\
\hline (1) & 1979 & 292452 & Br J Cancer, Palu G et al & AML cells into irradiated CBA mice \\
\hline (2) & 1984 & 6582788 & Am J Pathol, Potter GK et al & AML cell line into nude mice \\
\hline (3) & 1991 & 1893976 & Exp Hematol, De Lord C et al & AML cells into SCID \\
\hline (4) & 1993 & 8104540 & Exp Hematol, Reiko Namikawa et al & AML patient $B M$ cells into SCID \\
\hline (5) & 1994 & 7509044 & Nature, Lapidot T et al & AML initiating cell into SCID \\
\hline (6) & 1997 & 9212098 & Nat Med, Bonnet D et al & AML cells into NOD/SCID \\
\hline (7) & 1999 & 10477702 & Blood, Ailes LE et al & AML progenitor cells into NOD/SCID \\
\hline (8) & 1999 & 16234360 & Blood, Pearce DJ et al & AML cells into NOD/SCID \\
\hline (9) & 2002 & 12200698 & Leukemia, Lumkul R et al & AML cells into NOD/SCID \\
\hline (10) & 2006 & 16998484 & Nat Med, Jin L et al & AML cells targeting CD44 into NOD/SCID \\
\hline (11) & 2009 & 19570512 & Cell stem cell, Jin L et al & $\begin{array}{l}\text { Leukemic Stem cells w/CD123 monoclonal antibody into } \\
\text { NOD/SCID }\end{array}$ \\
\hline (12) & 2005 & 17952057 & Nat Biotechol, Ishikawa F et al & AML cells into NOD/SCID/IL2R $\gamma$ _null \\
\hline (13) & 2007 & 21157036 & J Clin Invest, Sarry JE et al & Leukemic Stem cells into NOD/SCID/IL2R $\gamma \_$null \\
\hline (14) & 2014 & 25069538 & Oncol Rep, Lee JY et al & $\begin{array}{l}\text { LPB, BM-derived ALDH }{ }^{\text {dim }} \mathrm{CD} 34^{+} \mathrm{CD} 38^{-} \text {cells into } \\
\text { NOD/SCID/L2R } 2 \text { _null }\end{array}$ \\
\hline
\end{tabular}

Fig. 2. Summary of hu-leukemic-mice model. To increase blast engraftment in BM, advanced mice model constantly has developed from nude mice model to NOD/SCID/IL2R $\gamma \_$null mouse. Based on these, modified stem cell sources transplanted to optimize leukemia model. 
Great benefits of NOD/SCID mice involve that successful engraftment of LSCs with high efficacy and low injected cells (Bonnet and Dick, 1997). Recently, most investigators prefer usage of NOD/SCID mice to investigate AML due to invariable probability in blast phenotype, morphology, and biologic properties (Ailles et al., 1999; Lumkul et al., 2002; Jin et al., 2006; Pearce et al., 2006; Jin et al., 2009). Nevertheless, incomplete NOD/SCID still exists including thymic lymphoma and high NK activity. Both mice, NOG mice by Ito $\mathrm{M}$ et al. and NSG mice by Shultz LD et al. displayed IL-R2 $\gamma^{\text {null }}$, which abrogated the activation of NK cells (Ito et al., 2002; Shultz et al., 2005). Furthermore, AML cell infiltration in endosteal niche was firstly detected by Ishikawa $\mathrm{F}$ et al. using NOD/SCID/IL2R $\gamma^{\text {null }}$ mice (Ishikawa et al., 2007). As part of these experiments, our group also reported that $\mathrm{CD} 34^{+} \mathrm{CD} 38^{-}$cells with high level of aldehyde dehydrogenase $^{\mathrm{dim}}\left(\mathrm{ALDH}^{\mathrm{dim}}\right)$ positive cells is a reliable marker to make stable hu-leukemic-mice model for drug screening (Lee et al., 2014). Based on advanced model development without cessation, identification of LSCs and HSCs will be quickly revealed by modifying the huleukemic mice model. History of hu-mice model for leukemia study is briefly presented by Fig. 2 .

\section{Application and perspectives of hu-leukemic mice model}

Regardless of the type of the cancer, the hu-mice model should be needed to investigate tumor microenvironmental explorer. Especially, interaction between immune cells and leukemic stem cells might be optimized through the huleukemic-mice model. Similar with hu-mice models, accomplishment of hu-leukemic-mice model for microenvironmental study gradually enlarged in their spectrum from vitro study to vivo model (Fig. 3). Most leukemia accompanied by an impaired immune system leads to the failure of blast suppression. Thus, immune cell modulation as a therapeutic target is an emerging issue in treating AML. Inhibition of SIRP $\alpha$ in macrophage can eradicate AML stem cells (Theocharides et al., 2012) and VEGFR-3 antagonist treated NK cells can directly kill the leukemic blast. Because of the VEGFR-3 ligand, VEGF-C abundant status can affect

\section{The Step for Humanized Mice Model}

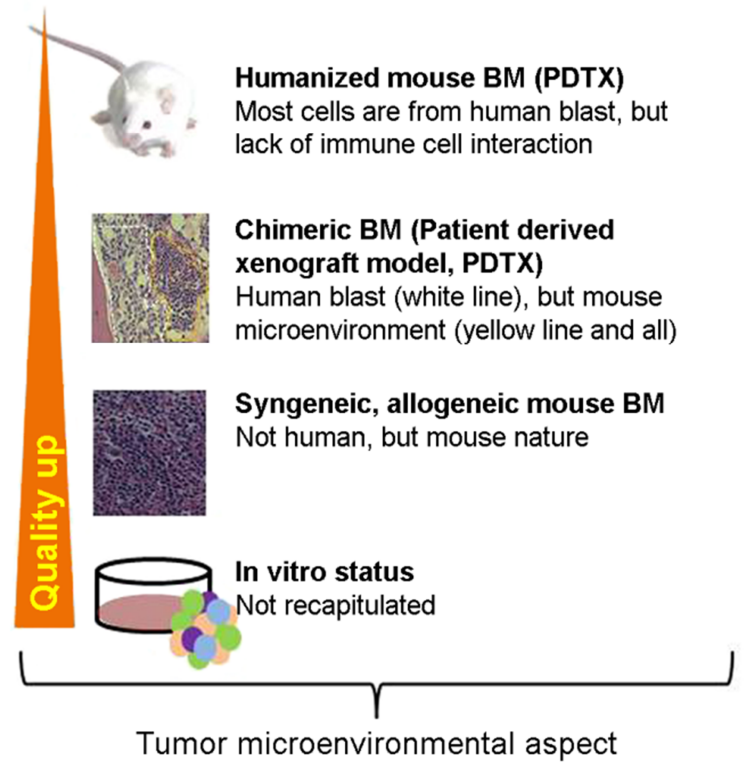

Fig. 3. Developments of hu-mice models. To mimic human condition, attempts have been developed from vitro/ex vivo study to in vivo hu-mice models. The latest version of hu-mice model has a limitation to investigate relevance between microenvironmental factor such as immune cells and hematopoietic stem cells. To overcome this, notable protocol should be developed such as sequential transplantation, which first build hu-mice model with normal HSC, and then induce leukemia condition.

immune cell inactivation (Lee et al., 2014) and the feasibility of as a niche therapy such as immune cell and MSCs modulation is consistently presented by several papers (Lee et al., 2014; Cogle et al., 2015; Kim et al., 2015; Ayala et al., 2009). Also, another arguing point is about the hierarchical relevance between malignant niche and leukemic stem cells. Recently, Boyerinas B et al. showed that dormant leukemic cells are governed by niche, suggesting autonomous leukemic stem cell function as an authorizer in a leukemic microenvironment (Boyerinas et al., 2013). Conversely, Flach $\mathrm{J}$ insists that conversion of normal HSC into malignant cells occur by DNA damage, implying the importance of niche in the driving of malignant cells (Flach et al., 2014). To elucidate the controversy, an accurate interpretation could be possible through reproducible and credible vivo model, hu-leukemic-mice model. In addition, the progress of stem cell biology following the application of induced pluripotent 
stem cells into the clinic and regenerative medicine will elevate the usability of the hu-mice model.

\section{CONCLUSION}

We briefly summarized the history of hu-mice model for immunology and pointed out the hu-disease mice model, especially for AML. Advanced hu-leukemic-mice models will contribute to analysis of machinery of underlying AML features and immunologic interaction. However, several concerns remain to be overcome, such as the standardization of individual variation in AML patients, successional expression of specific mutant genes including FLT3-ITD and $C B F B / M Y H 11$ in secondary/tertiary transplantation. To completely treat AML, a better understanding of the immune niche and LSCs mechanism is needed and effective therapeutic protocols might be accomplished by mimicking the hu-mice system.

\section{Acknowledgements}

This study was supported by Basic Science Research Program through the National Research Foundation of Korea (NRF) funded by the Ministry of Education (2014R1A1A2053407).

\section{Conflict of interests}

The authors declare that they have no conflict of interests.

\section{REFERENCES}

Ailles LE, Gerhard B, Kawagoe H, Hogge DE. Growth characteristics of acute myelogenous leukemia progenitors that initiate malignant hematopoiesis in nonobese diabetic/severe combined immunodeficient mice. Blood. 1999. 94: 1761-1772.

Ayala F, Dewar R, Kieran M, Kalluri R. Contribution of bone microenvironment to Leukemogenesis and leukemia progression. Leukemia. 2009. 23: 2233-2241.

Bonnet D, Dick JE. Human acute myeloid leukemia is organized as a hierarchy that originates from a primitive hematopoietic cell. Nat Med. 1997. 3: 730-737.

Bosma GC, Custer RP, Bosma MJ. A severe combined immunodeficiency mutation in the mouse. Nature. 1983. 301: 527-530. Boyerinas B, Zafrir M, Yesilkanal AE, Price TT, Hyjek EM, Sipkins
DA. Adhesion to osteopontin in the bone marrow niche regulates lymphoblastic leukemia cell dormancy. Blood. 2013. 121: 4821-4831.

Cao X, Shores EW, Hu-Li J, Anver MR, Kelsall BL, Russell SM, Drago J, Noguchi M, Grinberg A, Bloom ET, Paul WE, Katz SI, Love PE, Leonard WJ. Defective lymphoid development in mice lacking expression of the common cytokine receptor gamma chain. Immunity. 1995. 2: 223-238.

Christianson SW, Greiner DL, Schweitzer IB, Gott B, Beamer GL, Schweitzer PA, Hesselton RM, Shultz LD. Role of natural killer cells on engraftment of human lymphoid cells and on metastasis of human t-lymphoblastoid leukemia cells in c57bl/ 6j-scid mice and in c57bl/6j-scid bg mice. Cell Immunol. 1996. 171: 186-199.

Cogle CR, Bosse RC, Brewer T, Migdady Y, Shirzad R, Kampen $\mathrm{KR}$, Saki N. Acute myeloid leukemia in the vascular niche. Cancer Lett. 2015. (in press)

De Lord C, Clutterbuck R, Titley J, Ormerod M, Gordon-Smith T, Millar J, Powles R. Growth of primary human acute leukemia in severe combined immunodeficient mice. Exp Hematol. 1991. 19: 991-993.

DiSanto JP, Muller W, Guy-Grand D, Fischer A, Rajewsky K. Lymphoid development in mice with a targeted deletion of the interleukin 2 receptor gamma chain. Proc Natl Acad Sci U S A. 1995. 92: 377-381.

Ferrara F, Schiffer CA. Acute myeloid leukaemia in adults. Lancet. 2013. 381: 484-495.

Flach J, Bakker ST, Mohrin M, Conroy PC, Pietras EM, Reynaud D, Alvarez S, Diolaiti ME, Ugarte F, Forsberg EC, Le Beau MM, Stohr BA, Mendez J, Morrison CG, Passegue E. Replication stress is a potent driver of functional decline in ageing haematopoietic stem cells. Nature. 2014. 512: 198-202.

Goldman JP, Blundell MP, Lopes L, Kinnon C, Di Santo JP, Thrasher AJ. Enhanced human cell engraftment in mice deficient in rag2 and the common cytokine receptor gamma chain. Br J Haematol. 1998. 103: 335-342.

Humeau L, Namikawa R, Bardin F, Mannoni P, Roncarolo MG, Chabannon C. Ex vivo manipulations alter the reconstitution potential of mobilized human $\mathrm{CD} 34^{+}$peripheral blood progenitors. Leukemia. 1999. 13: 438-452.

Huntington ND, Legrand N, Alves NL, Jaron B, Weijer K, Plet A, Corcuff E, Mortier E, Jacques Y, Spits H, Di Santo JP. Il-15 trans-presentation promotes human NK cell development and differentiation in vivo. J Exp Med. 2009. 206: 25-34.

Ishikawa F, Yasukawa M, Lyons B, Yoshida S, Miyamoto T, 
Yoshimoto G, Watanabe T, Akashi K, Shultz LD, Harada M. Development of functional human blood and immune systems in nod/scid/il2 receptor $\{$ gamma\} chain(null) mice. Blood. 2005. 106: 1565-1573

Ishikawa F, Yoshida S, Saito Y, Hijikata A, Kitamura H, Tanaka S, Nakamura R, Tanaka T, Tomiyama H, Saito N, Fukata M, Miyamoto T, Lyons B, Ohshima K, Uchida N, Taniguchi S, Ohara O, Akashi K, Harada M, Shultz LD. Chemotherapyresistant human aml stem cells home to and engraft within the bone-marrow endosteal region. Nat Biotechnol. 2007. 25: 1315-1321.

Ito M, Hiramatsu H, Kobayashi K, Suzue K, Kawahata M, Hioki K, Ueyama Y, Koyanagi Y, Sugamura K, Tsuji K, Heike T, Nakahata T. Nod/scid/gamma(c)(null) mouse: An excellent recipient mouse model for engraftment of human cells. Blood. 2002. 100: 3175-3182.

Jin L, Hope KJ, Zhai Q, Smadja-Joffe F, Dick JE. Targeting of cd44 eradicates human acute myeloid leukemic stem cells. Nat Med. 2006. 12: 1167-1174.

Jin L, Lee EM, Ramshaw HS, Busfield SJ, Peoppl AG, Wilkinson L, Guthridge MA, Thomas D, Barry EF, Boyd A, Gearing DP, Vairo G, Lopez AF, Dick JE, Lock RB. Monoclonal antibodymediated targeting of cd123, il-3 receptor alpha chain, eliminates human acute myeloid leukemic stem cells. Cell Stem Cell. 2009. 5: 31-42.

Kfoury Y, Scadden DT. Mesenchymal cell contributions to the stem cell niche. Cell Stem Cell. 2015. 16: 239-253.

Kim JA, Shim JS, Lee GY, Yim HW, Kim TM, Kim M, Leem SH, Lee JW, Min CK, Oh IH. Microenvironmental remodeling as a parameter and prognostic factor of heterogeneous leukemogenesis in acute myelogenous leukemia. Cancer Res. 2015. 75: 2222-2231

Kollet O, Peled A, Byk T, Ben-Hur H, Greiner D, Shultz L, Lapidot T. Beta2 microglobulin-deficient (b2m(null)) nod/scid mice are excellent recipients for studying human stem cell function. Blood. 2000. 95: 3102-3105.

Konopleva M, Konoplev S, Hu W, Zaritskey AY, Afanasiev BV, Andreeff M. Stromal cells prevent apoptosis of aml cells by up-regulation of anti-apoptotic proteins. Leukemia. 2002. 16: 1713-1724.

Lapidot T, Pflumio F, Doedens M, Murdoch B, Williams DE, Dick JE. Cytokine stimulation of multilineage hematopoiesis from immature human cells engrafted in scid mice. Science. 1992. 255: 1137-1141.

Lapidot T, Sirard C, Vormoor J, Murdoch B, Hoang T, Caceres-
Cortes J, Minden M, Paterson B, Caligiuri MA, Dick JE. A cell initiating human acute myeloid leukaemia after transplantation into scid mice. Nature. 1994. 367: 645-648.

Lee JY, Park S, Min WS, Kim HJ. Restoration of natural killer cell cytotoxicity by vegfr-3 inhibition in myelogenous leukemia. Cancer Lett. 2014. 354: 281-289.

Lee JY, Park S, Han AR, Lim J, Min WS, Kim HJ. High aldhdimexpressing $\mathrm{CD}^{-} 4^{+} \mathrm{CD} 38^{-}$cells in leukapheresed peripheral blood is a reliable guide for a successful leukemic xenograft model of acute myeloid leukemia. Oncol Rep. 2014. 32: 1638 $-1646$.

Lee JY, Kim HJ. (Lymph)angiogenic influences on hematopoietic cells in acute myeloid leukemia. Exp Mol Med. 2014. 46: e122.

Lion E, Willemen Y, Berneman ZN, Van Tendeloo VF, Smits EL. Natural killer cell immune escape in acute myeloid leukemia. Leukemia. 2012. 26: 2019-2026.

Lubin I, Faktorowich Y, Lapidot T, Gan Y, Eshhar Z, Gazit E, Levite M, Reisner Y. Engraftment and development of human $t$ and $\mathrm{b}$ cells in mice after bone marrow transplantation. Science. 1991. 252: 427-431.

Lumkul R, Gorin NC, Malehorn MT, Hoehn GT, Zheng R, Baldwin B, Small D, Gore S, Smith D, Meltzer PS, Civin CI. Human aml cells in nod/scid mice: Engraftment potential and gene expression. Leukemia. 2002. 16: 1818-1826.

McCune JM, Namikawa R, Kaneshima H, Shultz LD, Lieberman M, Weissman IL. The scid-hu mouse: Murine model for the analysis of human hematolymphoid differentiation and function. Science. 1988. 241: 1632-1639.

Mercier FE, Ragu C, Scadden DT. The bone marrow at the crossroads of blood and immunity. Nat Rev Immunol. 2012. 12: 49-60.

Mombaerts P, Iacomini J, Johnson RS, Herrup K, Tonegawa S, Papaioannou VE. Rag-1-deficient mice have no mature $b$ and t lymphocytes. Cell. 1992. 68: 869-877.

Mosier DE, Gulizia RJ, Baird SM, Wilson DB. Transfer of a functional human immune system to mice with severe combined immunodeficiency. Nature. 1988.335:256-259.

Namikawa R, Kaneshima H, Lieberman M, Weissman IL, McCune JM. Infection of the scid-hu mouse by HIV-1. Science. 1988. 242: 1684-1686.

Ohbo K, Suda T, Hashiyama M, Mantani A, Ikebe M, Miyakawa K, Moriyama M, Nakamura M, Katsuki M, Takahashi K, Yamamura K, Sugamura K. Modulation of hematopoiesis in mice with a truncated mutant of the interleukin-2 receptor 
gamma chain. Blood. 1996. 87: 956-967.

Palu G, Selby P, Powles R, Alexander P. Spontaneous regression of human acute myeloid leukaemia xenografts and phenotypic evidence for maturation. Br J Cancer. 1979. 40: 731-735.

Pantelouris EM. Absence of thymus in a mouse mutant. Nature. 1968. 217: 370-371.

Pearce DJ, Taussig D, Zibara K, Smith LL, Ridler CM, Preudhomme C, Young BD, Rohatiner AZ, Lister TA, Bonnet D. Aml engraftment in the nod/scid assay reflects the outcome of aml: Implications for our understanding of the heterogeneity of aml. Blood. 2006. 107: 1166-1173.

Potter GK, Shen RN, Chiao JW. Nude mice as models for human leukemia studies. Am J Pathol. 1984. 114: 360-366.

Sawyers CL, Gishizky ML, Quan S, Golde DW, Witte ON. Propagation of human blastic myeloid leukemias in the scid mouse. Blood. 1992. 79: 2089-2098.

Shpitz B, Chambers CA, Singhal AB, Hozumi N, Fernandes BJ, Roifman CM, Weiner LM, Roder JC, Gallinger S. High level functional engraftment of severe combined immunodeficient mice with human peripheral blood lymphocytes following pretreatment with radiation and anti-asialo gm1. J Immunol Methods. 1994. 169: 1-15.

Shultz LD, Ishikawa F, Greiner DL. Humanized mice in trans- lational biomedical research. Nat Rev Immunol. 2007. 7: 118 $-130$.

Shultz LD, Schweitzer PA, Christianson SW, Gott B, Schweitzer

IB, Tennent B, McKenna S, Mobraaten L, Rajan TV, Greiner DL, Leiter EH. Multiple defects in innate and adaptive immunologic function in nod/ltsz-scid mice. J Immunol. 1995. 154: 180-191.

Shultz LD, Lyons BL, Burzenski LM, Gott B, Chen X, Chaleff S, Kotb M, Gillies SD, King M, Mangada J, Greiner DL, Handgretinger R. Human lymphoid and myeloid cell development in nod/ltsz-scid il2r gamma null mice engrafted with mobilized human hemopoietic stem cells. J Immunol. 2005. 174: 6477-6489.

Theocharides AP, Jin L, Cheng PY, Prasolava TK, Malko AV, Ho JM, Poeppl AG, van Rooijen N, Minden MD, Danska JS, Dick JE, Wang JC. Disruption of sirpalpha signaling in macrophages eliminates human acute myeloid leukemia stem cells in xenografts. J Exp Med. 2012. 209: 1883-1899.

Zheng J, Umikawa M, Cui C, Li J, Chen X, Zhang C, Huynh H, Kang X, Silvany R, Wan X, Ye J, Canto AP, Chen SH, Wang HY, Ward ES, Zhang CC. Inhibitory receptors bind angptls and support blood stem cells and leukaemia development. Nature. 2012. 485: 656-660 